\title{
A two-dimensional glacier-fjord coupled model applied to estimate submarine melt rates and front position changes of Hansbreen, Svalbard
}

\author{
E. DE ANDRÉS, ${ }^{1}$ J. OTERO,${ }^{1}$ F. NAVARRO,${ }^{1}$ A. PROMIŃSKA, ${ }^{2}$ J. LAPAZARAN, ${ }^{1}$ \\ W. WALCZOWSKI ${ }^{2}$ \\ ${ }^{1}$ Department of Applied Mathematics, Universidad Politécnica de Madrid, Madrid, Spain \\ ${ }^{2}$ Institute of Oceanology, Polish Academy of Sciences, Sopot, Poland \\ Correspondence: Eva De Andrés <eva.deandres@upm.es>
}

\begin{abstract}
We have developed a two-dimensional coupled glacier-fjord model, which runs automatically using Elmer/Ice and MITgcm software packages, to investigate the magnitude of submarine melting along a vertical glacier front and its potential influence on glacier calving and front position changes. We apply this model to simulate the Hansbreen glacier-Hansbukta proglacial-fjord system, Southwestern Svalbard, during the summer of 2010. The limited size of this system allows us to resolve some of the small-scale processes occurring at the ice-ocean interface in the fjord model, using a $0.5 \mathrm{~s}$ time step and a $1 \mathrm{~m}$ grid resolution near the glacier front. We use a rich set of field data spanning the period April-August 2010 to constrain, calibrate and validate the model. We adjust circulation patterns in the fjord by tuning subglacial discharge inputs that best match observed temperature while maintaining a compromise with observed salinity, suggesting a convectively driven circulation in Hansbukta. The results of our model simulations suggest that both submarine melting and crevasse hydrofracturing exert important controls on seasonal frontal ablation, with submarine melting alone not being sufficient for reproducing the observed patterns of seasonal retreat. Both submarine melt and calving rates accumulated along the entire simulation period are of the same order of magnitude, $\sim 100 \mathrm{~m}$. The model results also indicate that changes in submarine melting lag meltwater production by 4-5 weeks, which suggests that it may take up to a month for meltwater to traverse the englacial and subglacial drainage network.
\end{abstract}

KEYWORDS: glacier ablation phenomena, glacier calving, glacier modeling, ice/ocean interactions

\section{INTRODUCTION}

At the time of the last IPCC report, the projected contributions to global mean sea-level rise (SLR) to the end of the $21 \mathrm{st}$ century by mass losses from glaciers and ice caps (henceforth, glaciers) were between 40 and $230 \mathrm{~mm}$, depending on emission pathway. This was similar to the projected contribution from the Greenland Ice Sheet $(40-210 \mathrm{~mm})$ and larger than that of the Antarctic Ice Sheet ( -40 to $140 \mathrm{~mm}$ ) (Church and others, 2013). More recent model projections of glacier contribution to SLR to the end of the 21st century range between 79 and $157 \mathrm{~mm}$ and suggest that losses by frontal ablation of tidewater glaciers (iceberg calving plus subaerial and submarine melting at the near-vertical calving front) may be important contributors for regions such as peripheral Antarctica, Svalbard and the Russian Arctic (Huss and Hock, 2015). The significance of this contribution is supported by the high sensitivity of tidewater glaciers to ocean forcing (Rignot and others, 2010; Motyka and others, 2013; Straneo and Heimbach, 2013; Luckman and others, 2015). The ocean directly influences glacier dynamics through heat exchange, leading to melting of the submerged ice front (Jenkins, 2011). The two main processes favoring submarine melting are the water circulation in the proglacial fjord or bay (Motyka and others, 2013; Sciascia and others, 2013) and the buoyant plume formed by subglacial fresh water inputs at the grounding line. Subglacial fresh water inputs mainly come from surface meltwater (SMW) runoff (Xu and others, 2013; Cowton and others, 2015; Slater and others, 2015), and enhance convective fjord circulation. Submarine melting influences ice dynamics, since it causes loss of mass at the glacier terminus, changing the geometry of the glacier front and, consequently, producing stress field deviations (e.g. loss of buttressing and/or increase of buoyancy) that might favor calving ( $\mathrm{O}^{\prime}$ Leary and Christoffersen, 2013).

Parameterizations of submarine melting have been developed (Holland and Jenkins, 1999; Jenkins, 2011) and implemented as boundary conditions in numerical models (Xu and others, 2012; Cowton and others, 2015), which has allowed the community to gain knowledge on the key processes controlling the behavior of the glacier-fjord systems. Seasonality, temperature and salinity of seawater and fjord circulation patterns have been shown to be crucial in submarine melting (Motyka and others, 2013; Sciascia and others, 2013). Fjord geometry may also affect submarine melting in different ways. For example, the bathymetry influences flow patterns, the presence of a sill can block warmer, deeper water from entering the fjord, or grounding line depth controls the freezing-point temperature (Carroll and others, 2016; Seroussi and others, 2017). Features related to fresh water subglacial discharge and buoyant plume evolution, such as number and shape of discharge channels, flow intensity and entrainment rates, also play a key role (Xu and others, 2013; Carroll and others, 2015; Cowton 
and others, 2015, 2016; Slater and others, 2015, 2016, $2017 \mathrm{~b})$. Yet, many aspects of submarine melt in fjord models remain to be understood. Previous modeling studies have all relied on idealized geometries and use steady temperature and salinity boundary conditions, so that the circulation in the fjord is not transient. Therefore, the temporal evolution of water properties is not considered in spite of its direct impact on submarine melt rates (SMR) (Sciascia and others, 2013).

Calving, together with submarine melting, accounts for up to $46 \%$ of the net mass loss from Svalbard glaciers (Blaszczyk and others, 2009; Aas and others, 2016; Østby and others, 2017), and influences the glacier's dynamic behavior (Van der Veen, 1996; Nick and others, 2010). Seasonal variability observed in calving has been related to the backstress exerted by the ice mélange that is present during the colder seasons (Todd and Christoffersen, 2014; Otero and others, 2017). The mechanisms suggested to control calving (during the period when ice mélange is absent) include crevasse propagation near the glacier front (Benn and others, 2007), SMW filling crevasses (or leaking through them, thus weakening the ice matrix) (Otero and others, 2010; Cook and others, 2012), erosion driven by waves at the sea waterline (Petlicki and others, 2015) and melting of the submerged ice front wall (O'Leary and Christoffersen, 2013; Todd and Christoffersen, 2014; Vallot and others, 2018). Todd and Christoffersen (2014) suggested that submarine melting could be a second-order mechanism in triggering calving for tidewater glaciers. However, submarine melting has recently demonstrated to exert a primary control on calving at the Kronebreen glacier (in Svalbard) at the seasonal scale. Studies carried out for different systems (Thwaites Glacier in Antarctica, whose ice shelf has a buttressed portion grounded on an ice rise) have also shown that submarine melting has significant effects on the rate of grounding line retreat (Seroussi and others, 2017). Submarine melting may thus have a first-order effect in some marine-terminating glaciers but not in others. Fully coupled glacier-ocean numerical models are expected to reproduce observations more accurately and can thus be of help in clarifying the effects of submarine melting under different glacier-ocean settings.

In this study, we use a tow-dimensional (2-D) ( $x-z$ plane) high-resolution glacier-fjord coupled model to investigate whether submarine melting exerts an important control on calving rates and glacier front position changes in a glacier-fjord system with observed bathymetry in the Svalbard archipelago: Hansbreen-Hansbukta. The choice of a small glacier-fjord system, with a rich set of available data, allows us to implement a high-resolution fjord circulation model able to capture some of the small-scale processes taking place at the ice-ocean interface, resulting in more accurate estimates of submarine melting of the submerged glacier face. Importantly, our coupled model is applied to a tidewater glacier with vertical and evolving calving front, and includes fresh water inputs from subglacial discharge.

\section{STUDY AREA AND DATA}

\subsection{Glacier-fjord system}

We focus our study on the Hansbreen Glacier-Hansbukta Fjord system, which is a branch of the Hornsund fjord, located in Southern Spitsbergen, Svalbard, at $\sim 77^{\circ} \mathrm{N}$ (Fig. 1).
The Svalbard archipelago is of a particular interest because marine-terminating glaciers constitute $44 \%$ of its glacierized area (Pfeffer and others, 2014). Although in recent years its mass losses from glacier wastage have been the lowest of all Arctic regions (Gardner and others, 2013), these losses have been predicted to increase substantially to the end of the 21st century (Huss and Hock, 2015; Lang and others, 2015; Möller and others, 2016).

Hansbreen is a tidewater glacier $\sim 16 \mathrm{~km}$ long and $2.5 \mathrm{~km}$ wide. It has a $1.5 \mathrm{~km}$-wide calving front, with a vertical face that is $\sim 100 \mathrm{~m}$ thick at the central flowline, of which 50-60 $\mathrm{m}$ are submerged. The bed of the central flowline lies below sea level as far as $10 \mathrm{~km}$ up-glacier from the terminus, with the $4 \mathrm{~km}$ closest to the terminus overlying a reverse-slope bed (Fig. 2). Surface velocity increases toward the terminus, reaching values up to $\sim 7 \mathrm{~m}^{\text {week }}{ }^{-1}$. Velocities vary seasonally, reaching maxima during late spring-early summer. Iceberg calving usually starts in May and ends in October, and the mean annual calving rate is $250 \mathrm{~m} \mathrm{a}^{-1}$ (Blaszczyk and others, 2009).

Hansbukta is Hansbreen's $\sim 2 \mathrm{~km}$-long proglacial fjord. It is a shallow fjord ( $<80 \mathrm{~m}$ depth), with a prominent and long sill of $\sim 25 \mathrm{~m}$ depth that extends toward the fjord mouth (Fig. 2). Hornsund region is characterized by a relatively warm and humid climate due to the influence of the West Spitsbergen Current, which carries warm and salty Atlantic waters that mix with the fresher and cooler fjord waters during the summer season (Cottier and others, 2010; Walczowski and Piechura, 2011). The heat exchange taking place between water masses strongly influences submerged-ice melting.

\subsection{Data}

Observational constrains on the glacier model include surface velocities, front positions, ice-melánge coverage, surface elevation, bedrock topography and surface massbalance (SMB) estimates. Ice surface velocities (Fig. 3a) were measured daily, from May 2005 to April 2011, at stakes located close to the flowline (Puczko, 2012) and from terrestrial laser scanner for the velocities at the glacier terminus (Otero and others, 2017). Front position data and ice-mélange coverage from time-lapse camera images taken every $3 \mathrm{~h}$ (Fig. $3 \mathrm{~b}$ ) were processed and averaged over weekly intervals between December 2009 and September 2011 (Otero and others, 2017). SMB was obtained from European Arctic Reanalysis (EAR) data, with $2 \mathrm{~km}$ horizontal resolution and hourly temporal resolution, constrained by automatic weather stations and stake observations (Finkelnburg, 2013). First, ablation was calculated from the surface energy balance (SEB), which is resolved in the EAR by an optimized version of the unified NOAA Land Surface Model (Chen and Dudhia, 2001) of the Polar WRF 3.4.1 model. The algorithm solving for the SEB takes into account net radiation, sensible heat flux, latent heat flux and heat flux across the glacier surface for glacierized areas and across the ground for non-glacierized areas, and encompasses all heat fluxes involved in melt and refreezing processes within the snowpack. Second, accumulation was obtained as the solid (frozen) precipitation of the Morrison bulk microphysics scheme for cloud physics used by the EAR. Finally, monthly mean SMB and SMW at each flowline point were calculated by applying bilinear interpolation to the available $2 \mathrm{~km}$ resolution hourly accumulation and 


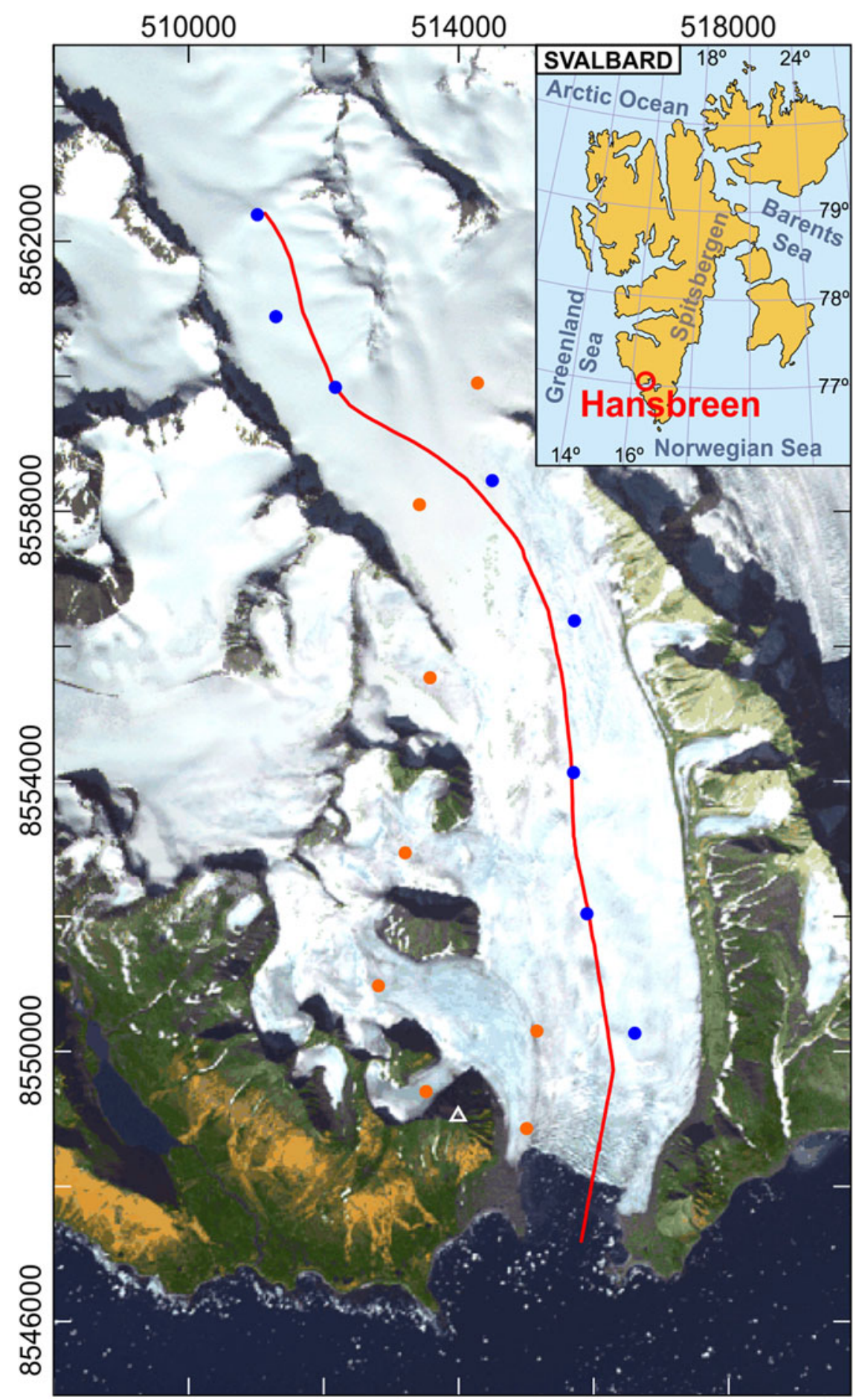

Fig. 1. Location of Hansbreen-Hansbukta, Svalbard (inset). ASTER image of Hansbreen-Hansbukta showing the location of the modeled flowline (red line) and the locations of the stakes for velocity measurements (colored circles). Only the velocity stakes marked with blue dots were used in our analysis. The white triangle indicates the position of the time-lapse camera. The axes include the UTM coordinates (m) for zone 33X.
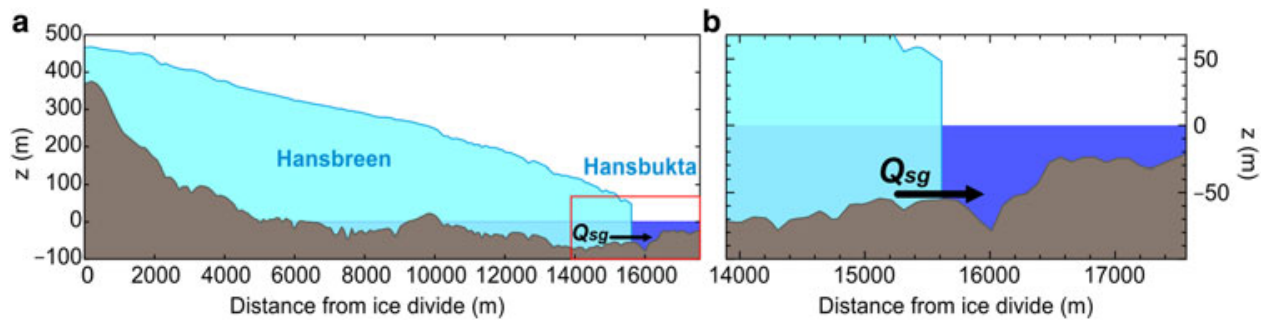

Fig. 2. Hansbreen-Hansbukta system model domain (left), and a detail of Hansbukta (right). 

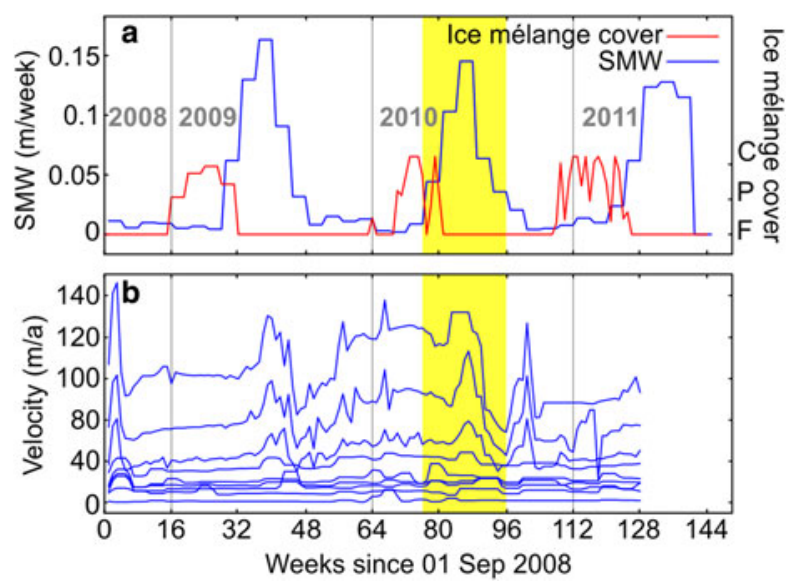

Fig. 3. Time evolution of: (a) sea-ice coverage (red) and surface meltwater estimations (blue); (b) surface velocities in Hansbreen. Velocities increase near the glacier front. The yellow region indicates the overlapping period when both glacier and fjord data are available (April to August of 2010).

ablation data (Fig. 3b). The surface elevation came from the SPIRIT Digital Elevation Model (DEM) for gentle slopes, with a $30 \mathrm{~m}$ root-mean-square absolute horizontal precision and $40 \mathrm{~m}$ resolution. Bedrock topography was inferred from ground-penetrating radar data (Grabiec and others, 2012; Navarro and others, 2014).

Available oceanographic data overlap glaciological data only for 5 months, limiting our coupled modeling from April to August of 2010 ( 20 weeks). During this period, several water temperature and salinity data sets were collected in Hansbukta (Fig. 4) using a SBE 19plus Conductivity-Temperature-Depth (CTD) probe, profiling with a frequency of $4 \mathrm{~Hz}$ with an initial accuracy of $0.0005 \mathrm{~S} \mathrm{~m}^{-1}$ for conductivity, $0.005^{\circ} \mathrm{C}$ for temperature and $0.1 \%$ of full-scale range for pressure. All the data were vertically averaged every $1 \mathrm{dbar}(1 \mathrm{kPa})$. From April to August, data gaps in temperature and salinity were linearly interpolated, maintaining the vertical structure of the water column (i.e. the interpolation was applied to each vertical level). The 2-D model domain of Hansbreen was extended into Hansbukta, using bathymetry linearly interpolated from depth soundings measured at irregular intervals of $\sim 100 \mathrm{~m}$ (Vieli and others, 2002). Bathymetry varies from 55 to 25 $\mathrm{m}$ depth (glacier front and sill, respectively), reaching the maximum depth of $79 \mathrm{~m}$ at 200 to $400 \mathrm{~m}$ down-fjord from the glacier front (depending on glacier front position).

\section{THE COUPLED MODEL}

\subsection{Fjord circulation and submarine melt models}

We use a simplified 2-D ( $x-z$ coordinates) model of water circulation inside the fjord, which includes a source of mass at the grounding point and oceanic forcing at the fjord mouth. Atmospheric forcing, waves, tides or ice-mélange melting are not considered in our present study. We use the Navier-Stokes set of equations for incompressible and stratified fluid in a non-rotating system (Coriolis effects can be neglected, since the Rossby number for the modeled system is $\sim 10)$. The equations driving the fluid dynamics are conservation of mass (1), budget of momentum (2), heat (3) and salt (4). The model variables are: velocity vector $(\mathbf{u})$, temperature $(T)$, salinity $(S)$ and pressure $(p)$. To estimate the density of sea water $(\rho)$ as a function of temperature and salinity, we use the non-linear equation of state of Jackett and Mcdougall (1995), setting the reference density as $\rho_{0}=1027 \mathrm{~kg} \mathrm{~m}^{-3}$. Assuming the Boussinesq approximation, where $\rho=\rho_{0}+\rho^{\prime}(x, z, t)$, with $\left|\rho^{\prime}\right| \ll \rho_{0}$, the governing equations take the form:

$$
\begin{gathered}
\nabla \cdot \mathbf{u}=0, \\
\frac{\mathrm{d} \mathbf{u}}{\mathrm{d} t}=\mathbf{g}-\frac{1}{\rho_{0}} \nabla p+A \nabla^{2} \mathbf{u}, \\
\frac{\mathrm{d} T}{\mathrm{~d} t}=K_{\mathrm{T}} \nabla^{2} T, \\
\frac{\mathrm{d} S}{\mathrm{~d} t}=K_{\mathrm{S}} \nabla^{2} S,
\end{gathered}
$$

where $\mathbf{g}$ is the gravity acceleration vector, $A$ is the kinematic viscous coefficient (Laplacian Eddy Viscosity, assumed to be horizontally and vertically invariant) and $K_{\mathrm{T}, \mathrm{S}}$ are the thermal and haline diffusive coefficients. The 2-D configuration is a major simplification that does not allow the model to reproduce dynamical processes in the $y$-direction, which can be partially compensated by a proper choice of the viscous and diffusive coefficient values. Considering our aims of simulating both fjord circulation (with likely laminar flow regime) and buoyant plume at the glacier face (with potentially turbulent flow regime), the assumption that the viscous and diffusive coefficients are independent of position and velocity (both horizontally and vertically) is also a major simplification that might limit the capability to simulate turbulent flows embedded in stratified environments. The advantage of using a 2-D model is the capability of performing a large number of high-resolution simulations with reduced computational cost as compared with a 3-D model. By contrast, the 2-D fjord model represents a fjord where processes are assumed to be invariant in the $y$-direction, which is unlikely to happen in the real system. Key points of the real system not captured by the 2-D model are that discharge channels are not evenly distributed along the entire fjord width and that advective fluxes in the $y$-direction change the velocity fields and redistribute fjord water properties in a more complex way.

We use the Massachusetts Institute of Technology general circulation model (MITgcm; Marshall and others, 1997) to solve the non-hydrostatic form of the above equations on a generalized curvilinear grid, vertically fixed on z-levels. The finite-volume discretization follows the Arakawa C-grid (see Arakawa and Lamb, 1977) and we rendered it horizontally variable in the $x$-direction on a structured cell grid.

We set a 2-D fjord domain of $\sim 2 \mathrm{~km}$ in length along the $x$-coordinate (extension of the glacier central flowline), varying according to changes in glacier-front position (Fig. 2). The mesh consisted of $200 \times 90$ cells (horizontal-vertical). To capture small-scale processes, we set a high-resolution $x$-zone of $1 \mathrm{~m}$ gridcell length for the $100 \mathrm{~m}$ closest to the glacier front, and then linearly increasing to the end of the domain. The gridcell height along the $z$-coordinate was fixed to $1 \mathrm{~m}$. The model width in the $y$-direction is one gridcell of $1 \mathrm{~m}$. Sensitivity analyses were performed to constrain the optimal values of the diffusion coefficients, based on best-fit salinity profiles inside the fjord (temperature was less sensitive). We used the run-time week 17 due to the 


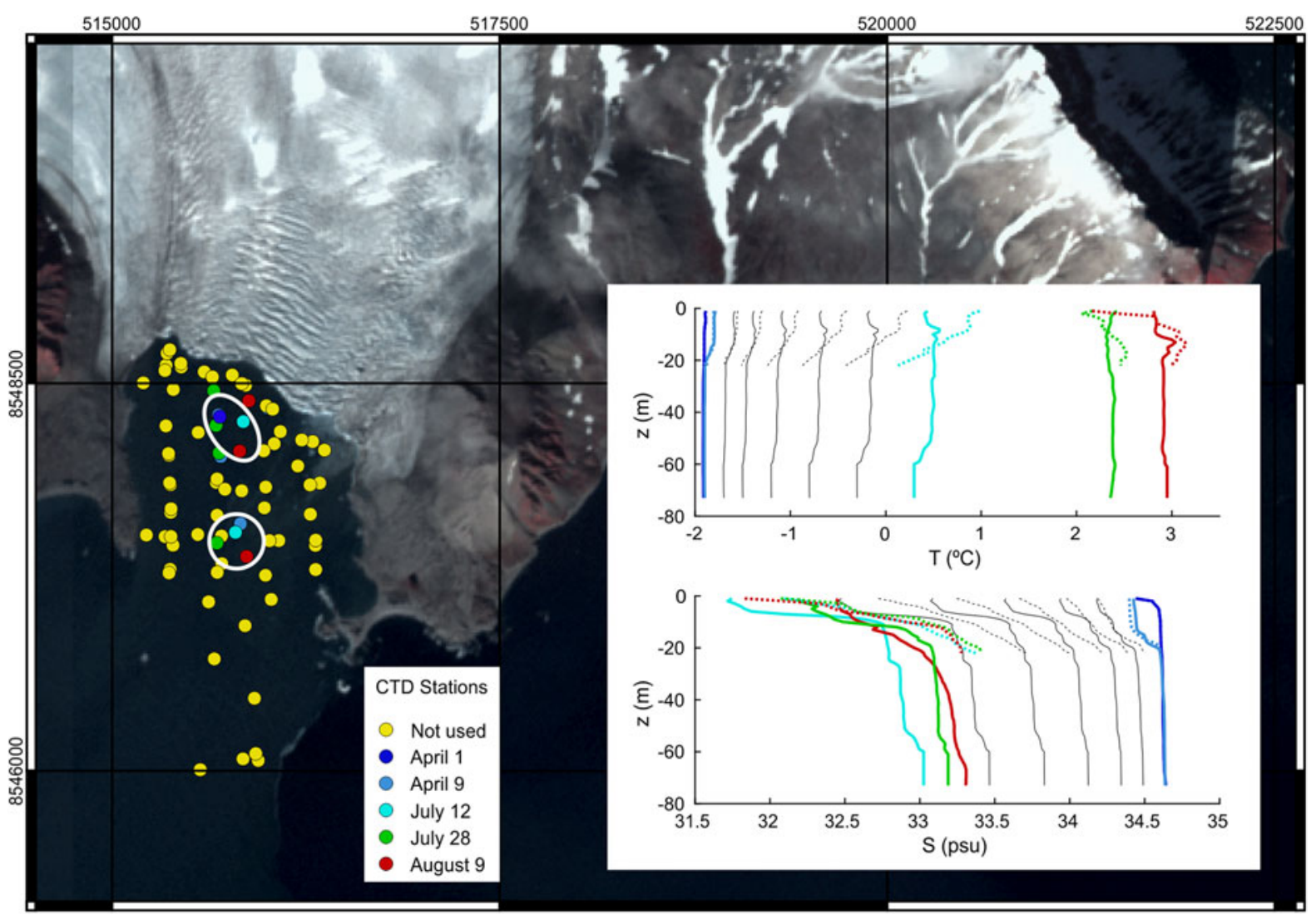

Fig. 4. Map of CTD stations in Hansbukta, during the oceanographic surveys in spring-summer of 2010. The data of the stations with maximum depth, contained in the white ellipse close to the glacier front, were used to set the initial conditions. The stations inside the white circle farther away from the front were located on the sill, and their data were used to prescribe the boundary conditions. Data from all non-yellow CTD stations were used for comparison with model results. The panel to the right shows the time evolution of the observed temperature ( $T$, upper panel) and salinity $(S$, lower panel) profiles set as initial (solid lines) and boundary (dotted lines) conditions. The temporal evolution is represented by colors as indicated by the legend for the CTD stations, and black lines represent profiles linearly interpolated in time.

warm temperatures of the fjord waters and to the salinity stratification at the top layer, which allowed us to compare the different patterns of modeled profiles resulting from different values of the diffusive coefficients. We tested values of $K_{\mathrm{T}, \mathrm{S}}$ in the range from $10^{-3}$ to $10^{-1} \mathrm{~m}^{2} \mathrm{~s}^{-1}$ with constant subglacial discharge velocities of $0.1 \mathrm{~m} \mathrm{~s}^{-1}$, obtaining the best fit for values of $K_{\mathrm{T}, \mathrm{S}}=1.4 \times 10^{-3} \mathrm{~m}^{2} \mathrm{~s}^{-1}$. We could assume that the flow is fully turbulent inside the buoyant plume and set heat and salt diffusivities equal to the kinematic eddy viscosity (McPhee and others, 1987). However, this cannot be assumed for the circulation in the rest of the fjord, where one must distinguish between viscous and diffusive processes. Therefore, Laplacian viscosity $\left(A_{\mathrm{h}, \mathrm{v}}\right)$ was set to $1.4 \times 10^{-2} \mathrm{~m}^{2} \mathrm{~s}^{-1}$ to match the expected order of magnitude of the Prandtl number for sea water $\left(10^{1}\right)$. We found the value of $A$ to be consistent with previous studies for the same spatial resolution ( $\mathrm{Xu}$ and others, 2013). The top boundary of the domain (sea level) was considered as a free surface, while the bottom (seabed) was set as a closed boundary (no normal flux, no tracer gradients) following the observed bathymetry with no-slip conditions (no tangential movement). The left side of the domain (glacier front) was also considered as a permanently vertical closed boundary with no-slip conditions in the fjord model. The right side (the fjord mouth) was set as an open boundary with transient temperature and salinity profiles according to the observed oceanic forcing. A more detailed explanation on transient forcing at the open boundary is as follows: the temperature and salinity profiles at the beginning of a given 1 -week simulation are set as those observed at the fjordmouth-CTD station for the date under consideration (or interpolated from data when they were not available, see Figs 4c, d) and we get the transient boundary conditions by linearly interpolating every time step toward next-week observations. A sponge boundary layer of five gridcells was set next to the right boundary to relax the numerical solution to the prescribed boundary values while minimizing unwanted perturbations (Israeli and Orszag, 1981). We set a time step of $0.5 \mathrm{~s}$, to ensure that the Courant-Friedich-Levy (CFL) stability criterion is met. A spin-up period of 1 week is run in a standalone ocean configuration to get initial velocity fields for the first fjord circulation period (kinetic energy of the system became stationary after $<1 \mathrm{~d}$ ). The model is reinitialized every week to get glacier model feedback (updated geometry). The velocity fields reached at the end of every 1 -week period are set as initial conditions for the subsequent one in order to maintain the continuity of the modeled water circulation patterns. In the case of salinity and temperature, for simplicity, we use the observed temperature and salinity profiles, measured at the deepest CTD station, and prescribe them along the entire horizontal grid. Thus, initial conditions of temperature and salinity inside the fjord are considered horizontally uniform, which did not imply any significant difference in the model results when compared with those 
obtained using observed/interpolated profiles from CTDs. The reason is that the model reaches a quasi-steady state in $<1 \mathrm{~d}$ and that first day is not taken into account when calculating weekly averaged SMR or vertically averaged temperatures and salinities.

We introduced subglacial discharge fluxes by constantly adding fresh water at the local freezing-point temperature (pressure-dependent, Eqn (5)), through one cell $\left(1 \mathrm{~m}^{2}\right)$ located at the glacier front grounding point. The added fresh water mass was balanced by prescribed barotropic velocities across the open boundary (Cowton and others, 2016).

MITgcm allows us to calculate SMR using the 'ice-front' package developed by $\mathrm{Xu}$ and others (2012), based on earlier work by Losch (2008), and slightly modified by Slater and others (2015), which solves the three-equation parametrization of the thermodynamical equilibrium at the ice-ocean interface (Holland and Jenkins, 1999; Jenkins, 2011):

$$
\begin{gathered}
T_{\mathrm{b}}=a S_{\mathrm{b}}+b+c p_{\mathrm{b}}, \\
C_{\mathrm{pw}} \rho \gamma_{\mathrm{T}}\left(T-T_{\mathrm{b}}\right)=-q\left[L_{\mathrm{f}}+C_{\mathrm{pi}}\left(T_{\mathrm{i}}-T_{\mathrm{b}}\right)\right], \\
\rho \gamma_{\mathrm{S}}\left(S-S_{\mathrm{b}}\right)=-q\left(S_{\mathrm{b}}-S_{\mathrm{i}}\right) .
\end{gathered}
$$

Equation (5) states how the freezing-point temperature at the boundary $\left(T_{\mathrm{b}}\right)$ depends on local pressure $\left(p_{\mathrm{b}}\right)$ and salinity $\left(S_{\mathrm{b}}\right)$. Equations (6) and (7), where $T$ and $S$ are the temperature and salinity inside the plume, express the heat and salt budgets at the ice-ocean interface for a given melt rate of ice, $q$. Subscripts $b, i$ and $w$ indicate boundary, ice and water, respectively. Turbulent transference of heat and salt $\left(\gamma_{\mathrm{T}, \mathrm{S}}\right)$ is considered proportional to the vertical velocity $(w)$ right next to the glacier front wall:

$$
\gamma_{\mathrm{T}, \mathrm{S}}=C_{\mathrm{d}}^{1 / 2} \Gamma_{\mathrm{T}, \mathrm{S}}|W|
$$

where $C_{d}^{1 / 2}$ and $\Gamma_{\mathrm{T}, \mathrm{S}}$ are the drag and turbulent-transfer coefficients, respectively. Despite the lack of universality and assuming the potential errors that can be introduced when estimating SMR, we take the values proposed by Jenkins and others (2010) for the thermal and haline Stanton numbers $\left(C_{d}^{1 / 2} \Gamma_{\mathrm{T}, \mathrm{S}}\right)$. Definitions and values of all parameters used can be found in Table 1 .

\subsection{Glacier model}

\subsubsection{Dynamical model equations and flow law}

The ice flow model has been described in previous work (Otero and others, 2017), so we only include the essential details below.

Ice is treated as an incompressible viscous fluid. The Stokes system of equations is used to model the dynamics of glacier ice. Since a 2-D flowline glacier model is implemented, important 3-D processes such as the confluence of tributaries, the effect on volume conservation of changes in channel width and lateral drag from the glacier margins are neglected. Little can be done to address the effect of tributaries without switching to a 3-D geometry, but by measuring the channel width at the surface and making assumptions about the channel geometry, we are able to estimate the lateral drag and its contribution to the flowline force balance. A parabolic shape is assumed and a body force term is added to the conservation of linear momentum equation to account, in a 2-D model, for friction from the shear margins (Jay-Allemand and others, 2011). As constitutive relation, we adopt Nye's generalization of Glen's flow law. We introduce a scalar damage variable that quantifies the loss of load-bearing surface area due to fractures, known as fracture-induced softening.

The time evolution of the glacier surface is calculated by solving the free-surface evolution equation that takes into account the flow of ice and the SMB.

As boundary conditions, we consider the upper surface of the glacier to be a traction-free boundary with no explicit boundary conditions on velocities. At the ice divide, horizontal velocity and shear stresses are set to zero. At the bed, we use a friction law that relates the sliding velocity to the basal shear stress in such a way that the latter is not set as an external boundary condition but becomes part of the solution. The space-dependent friction coefficient is determined using an inverse Robin method

\begin{tabular}{|c|c|c|c|}
\hline Symbol & Description & Value & Units \\
\hline \multicolumn{4}{|c|}{ Fjord circulation } \\
\hline$A_{\mathrm{H}, \mathrm{V}}$ & Horizontal and vertical diffusion of momentum & $1.4 \times 10^{-2}$ & $\mathrm{~m}^{2} \mathrm{~s}^{-1}$ \\
\hline$K_{\mathrm{H}, \mathrm{V}}^{\mathrm{\top}}$ & Horizontal and vertical diffusion of temperature & $1.4 \times 10^{-3}$ & $\mathrm{~m}^{2} \mathrm{~s}^{-1}$ \\
\hline$K_{\mathrm{H}, \mathrm{V}}^{\mathrm{S}}$ & Horizontal and vertical diffusion of salt & $1.4 \times 10^{-3}$ & $\mathrm{~m}^{2} \mathrm{~s}^{-1}$ \\
\hline$\rho_{0}$ & Density reference of seawater & 1027 & $\mathrm{~kg} \mathrm{~m}^{-3}$ \\
\hline \multicolumn{4}{|c|}{ Submarine melting } \\
\hline$C_{\mathrm{pw}}$ & Specific heat capacity for seawater & 3974 & $\mathrm{~J} \mathrm{~kg}^{-1} \mathrm{~K}^{-1}$ \\
\hline$C_{\mathrm{pi}}$ & Specific heat capacity for ice & 2009 & $\mathrm{~J} \mathrm{~kg}^{-1} \mathrm{~K}^{-1}$ \\
\hline$C_{\mathrm{d}}^{1 / 2} \Gamma_{\mathrm{T}}$ & Thermal Stanton number & $1.1 \times 10^{-3}$ & \\
\hline$C_{d}^{1 / 2} \Gamma_{S}$ & Haline Stanton number & $3.1 \times 10^{-5}$ & \\
\hline$L_{\mathrm{f}}$ & Latent heat of fusion for ice & 334000 & $\mathrm{~J} \mathrm{~kg}^{-1}$ \\
\hline$a$ & Seawater freezing-point slope & $-5.73 \times 10^{-2}$ & ${ }^{\circ} \mathrm{C}$ \\
\hline$b$ & Seawater freezing-point offset & $8.32 \times 10^{-2}$ & ${ }^{\circ} \mathrm{C}$ \\
\hline
\end{tabular}
(Arthern and Gudmundsson, 2010; Jay-Allemand and others, 2011).

Table 1. Physical parameters used in the fjord model 
At the glacier terminus, we set backstress to zero above sea level and equal to the water-depth-dependent hydrostatic pressure below sea level. An additional backstress of $50 \mathrm{kPa}$, modeling the ice-mélange pressure, is applied to a fraction of the calving face, with a freeboard height of $0.5 \mathrm{~m}$ and a mean thickness of $4.5 \mathrm{~m}$, in the direction opposite to ice flow.

\subsubsection{Calving model}

We use a crevasse-depth calving criterion that assumes that calving is triggered by the downward propagation of transverse surface crevasses occurring near the calving front as a result of the extensional stress regime. Following Nye (1957), crevasse depth is calculated as the depth where the longitudinal tensile strain rate tending to open the crevasse equals the creep closure resulting from the ice overburden pressure. Calving is assumed to occur when surface crevasses reach the waterline.

Crevasse depths are calculated from the balance of forces:

$$
\sigma_{\mathrm{n}}=2 \tau_{\mathrm{e}} \operatorname{sgn}\left(\tau_{x x}\right)-\rho_{\mathrm{i}} g d+P_{\mathrm{w}},
$$

where $\sigma_{\mathrm{n}}$, the 'net stress', is positive for extension and negative for compression. The first term on the right-hand side of Eqn (9) represents the opening force of longitudinal stretching, adapted by Todd and Christoffersen (2014) from Otero and others (2010); $\tau_{\mathrm{e}}$ represents the effective stress, $\tau_{\mathrm{e}}^{2}=\tau_{x x}^{2}+\tau_{z x}^{2} \cdot \tau_{\mathrm{e}}$ is multiplied by the sign function of the longitudinal deviatoric stress, $\tau_{x x}$, to ensure that crevasse opening is only produced under longitudinal extension $\left(\tau_{x x}\right.$ $>0$ ). The second term on the right-hand side is the ice overburden pressure, which leads to creep closure, where $\rho_{\mathrm{i}}$ is the density of glacier ice, $g$ is the acceleration of gravity and $d$ is the crevasse depth. The last term represents the water pressure that contributes to crevasse opening, which is a function of the depth of water filling the crevasse.

Given the difficulties of measuring the depth of water in crevasses, we ran the model for a range of constant crevasse water depths (CWD, in $\mathrm{m}$ ), and for a parameterized time-varying CWD expressed as a linear function of the SMW (in m week ${ }^{-1}$ ). Denoting with $\Delta t_{\mathrm{g}}$ the glacier model time step (1 week), we set a direct relationship between both variables, as follows:

$$
f=\frac{\mathrm{CWD}}{\mathrm{SMW}} \frac{1}{\Delta t_{\mathrm{g}}}
$$

where $f$ is just a non-dimensional adjustable parameter used to parameterize the unknown CWD in terms of the SMW.

\subsubsection{Numerical solution}

At each time step, the glacier is divided into a rectangular mesh with ten vertical layers and a horizontal grid size of $\sim 50 \mathrm{~m}$ in the upper glacier and $\sim 25 \mathrm{~m}$ near the terminus. The Stokes system of equations is solved by a finite element method using Elmer/lce and the 2-D stress and velocity fields are computed along the glacier central flowline (Fig. 1). The new surface elevations are computed from the $\mathrm{SMB}$ input and the surface velocities obtained by solving the free-surface evolution equation, and the grid nodes are shifted vertically to fit the new geometry. At the terminus, the grid nodes are shifted down-glacier according to the velocity vector and the length of the time step, and the terminus position is updated according to the calving criterion. If for a given time step calving is produced, the model domain is remeshed assuming a vertical ice cliff. Otherwise, we preserve the shape of the front resulting from submarine melt undercutting (see next section).

Prognostic model runs were carried out with a $\sim 1$-week (1/48 of a year) time step. Every 4 weeks (four time steps), we ran an initialization process for the glacier model, which consisted of solving the Robin problem to force a best-fit basal friction coefficient to be used for the subsequent four model time steps. This initialization was done to minimize the misfit between the observed and modeled velocities.

\subsection{Coupling mechanisms}

Coupling between our glacier and fjord models is accomplished through two main mechanisms: (1) depth-dependent SMR calculated by the fjord model is averaged weekly (excluding the first day of simulation) and is used to modify the shape of the submerged part of the glacier front. The resulting changes in the front shape define a new glacier model domain, which implies changes in the stress regime calculated by the model. (2) Front position changes derived from the glacier dynamics model modify the fjord domain length. The submerged ice front (left fjord boundary) is assumed to remain vertical at any time (even in the absence of iceberg calving), since changes in ice front shape does not have a significant effect on plume dynamics or SMR (Slater and others, 2017a). Velocity fields in the fjord are linked to gridcell position rather than actual locations. Although this implies a potential shift of the fjord velocity field, we ensure coherent motion near the glacier front at each simulated period. Following Seroussi and others (2017), glacier and fjord models are run with different spatial and time resolutions to ensure appropriate simulation of the relevant processes involved in each model. They run asynchronously and automatically, exchanging information every modeled week. The choice of this frequency of intercommunication between both models is supported by two main arguments: (1) there is no significant variation in submarine melting within a single week of simulation, and (2) the glacier-model time step is 1 week. The total modeled time was 20 weeks: 17 weeks initialized and constrained by CTD observations (from 1 April to 9 August 2010, interpolated when no data availability) plus 3 extended weeks based on mooring data (Fig. S1). Note that our fjord model is unable to reproduce any variation of potential forcing with a timescale shorter than a week, such as short-term variations in subglacial discharge intensities (peaks in surface melting due to, e.g. strong rain events or surface temperature peaks) or sudden intrusions of Atlantic-water masses through the fjord mouth. Although the SMR might vary significantly as a result of these processes, the available observations are too sparse to account for them.

\section{EXPERIMENTS}

\subsection{Subglacial discharge tuning}

The aim of this experiment was to determine the subglacial discharge velocity $\left(u_{\mathrm{sg}}, \mathrm{m} \mathrm{s}^{-1}\right)$ that produces the best fit between modeled and observed vertically averaged temperature and salinity profiles in the fjord, evaluated every 2 weeks of simulation. In the absence of $u_{\mathrm{sg}}$ data, we previously constrained its range using runoff estimations (SMW) 
from dynamical downscaling of regional climate modeling (Finkelnburg, 2013). Between April and August of 2010, the range of modeled total fresh water runoff was between 3 and $9 \mathrm{~m}^{3} \mathrm{~s}^{-1}$. Considering a continuous and uniformly distributed subglacial discharge along the $1.5 \mathrm{~km}$ active front of Hansbreen, the discharge velocity through the groundingpoint cell would range from $2 \times 10^{-3}$ to $6 \times 10^{-3} \mathrm{~m} \mathrm{~s}^{-1}$. With this velocity range, the model is unable to reproduce the expected turbulent flow of the buoyant plume, thus underestimating SMR. As we searched for a compromise in representing both circulation in the fjord and submerged ice front melting, we analyzed the impact of various $u_{\mathrm{sg}}$ values up to $0.2 \mathrm{~m} \mathrm{~s}^{-1}$ (e.g. Sciascia and others, 2013; Slater and others, 2015). Taking into account that the maximum estimation of SMW is of $9 \mathrm{~m}^{3} \mathrm{~s}{ }^{-1}$, the latter $u_{\mathrm{sg}}$ value would correspond to a channel width of $45 \mathrm{~m}$. The associated fresh water input would have a disproportionate impact on fjord-water properties, by confining the plume to a $45 \mathrm{~m}$ width along the fjord. A proper treatment of different channel and fjord widths would require either a 3-D modeling or a more complex treatment in the $y$-direction.

We first performed a sensitivity analysis of modeled fjord properties to subglacial discharge intensities varying every 2 weeks. We did this by running the fjord model alone applying discharge velocities $\left(u_{\mathrm{sg}}\right)$ in the range from 0 to $0.2 \mathrm{~m} \mathrm{~s}^{-1}$ to assess the various possibilities derived from the mentioned limitations (see Supplementary information, Fig. S2). We also ran different model configurations of $u_{\mathrm{sg}}$ along the entire simulation period (see values in Table 2 ) to evaluate the evolution of fjord properties using the coupled model, and to analyze the open-boundary contribution in the absence of fresh water inputs.

\subsection{Submarine melting under three different scenarios of subglacial discharge}

After calibrating the best-fit input of fresh water, varying every 2 weeks in our simulations, we also tested how the modeled SMR at the glacier front would change under different configurations of $u_{\mathrm{sg}}$. For these simulations, we run the coupled model using a SMW-dependent CWD relation, with $f$-ratio $=75$. Despite having already estimated the $u_{\mathrm{sg}}$ velocities which best matched the observations, we were concerned about the 2-D limitations inherent to our model. Some $u_{\mathrm{sg}}$ values could do a better job at capturing the more localized plume dynamics at the expense of unrealistic freshening of the fjord waters, while other values reduce this overfreshening but at the expense of weaker overturning that does not draw in sufficient ocean water at the fjord mouth. Consequently, we performed additional simulations with $u_{\mathrm{sg}}$ values lower (zero) and higher (double) than those resulting from the best fit, in order to obtain potential information about our 2-D model behavior, and to evaluate the sensitivity of submarine melting to subglacial discharge intensity.

Scenario 0: $u_{\mathrm{sg}}$ is assumed to be zero during the entire simulation (Table 2). This allows us to analyze how submarine melting evolves throughout the summer in the absence of turbulent buoyant plumes (though weak laminar plumes are potentially formed as submerged ice melts), thus showing the effect of ocean thermal forcing alone. It also provides information about the contribution of the boundary conditions to the change of water fjord properties in the absence of fresh water inputs.

Scenario 1: It represents the best-fit $u_{\mathrm{sg}}$ obtained in the subglacial-discharge-tuning experiment, so it can be considered as the most realistic scenario for our 2-D coupled model (see values in Table 2). Scenario1 is also used to test the influence that submarine melting exerts on glacier front dynamics (see next experiment), as well as how sensitive SMR are to spatial grid resolution (see Supplementary material, Fig. S3).

Scenario 2: In this scenario, $u_{\mathrm{sg}}$ values are the same as in scenario 1 for weeks $1-12$, and then are doubled to the end of the modeling period (Table 2). This shift in $u_{\mathrm{sg}}$ represents possible sudden discharge events associated with more intense surface melting episodes not registered by our observations, and allows us to analyze the impact of the subsequent submarine ice melting on calving.

\subsection{The effects of submarine melting and CWD on glacier front dynamics}

In this experiment, we focus on two mechanisms controlling calving rates and front position changes during the summer: submarine melting (SMR) (Morlighem and others, 2016; Seroussi and others, 2017) and CWD (Cook and others, 2014; Otero and others, 2017). First, we analyze the contribution of submarine melting alone to calving and front position changes (Fig. 7a). We used the three different scenarios of subglacial discharge described above, while

Table 2. Time series of subglacial discharge velocities $\left(u_{\mathrm{sg}}\right)$ used under different models of subglacial discharge and scenarios of submarine melting, which are described in the text and shown in Figures 5, 6, respectively

\begin{tabular}{|c|c|c|c|c|c|}
\hline \multirow[t]{2}{*}{ Simulation week } & \multicolumn{5}{|c|}{$u_{\mathrm{sg}}\left(\mathrm{m} \mathrm{s}^{-1}\right)$} \\
\hline & Model 0 (scenario 0$)$ & Model 1 & Model 2 (scenario 1) & Model 3 (scenario 2) & Model 4 \\
\hline 1 & \multirow{10}{*}{0} & \multirow{2}{*}{\multicolumn{4}{|c|}{$10^{-3}$}} \\
\hline 3 & & & & & \\
\hline 5 & & \multirow{2}{*}{\multicolumn{4}{|c|}{$2 \times 10^{-3}$}} \\
\hline 7 & & & & & \\
\hline 9 & & \multicolumn{3}{|c|}{$5 \times 10^{-3}$} & $10^{-2}$ \\
\hline 11 & & \multirow[b]{2}{*}{$5 \times 10^{-3}$} & \multirow{2}{*}{$10^{-2}$} & \multirow{2}{*}{$2 \times 10^{-2}$} & $3 \times 10^{-2}$ \\
\hline 13 & & & & & $\overline{4 \times 10^{-2}}$ \\
\hline 15 & & \multirow{3}{*}{$2 \times 10^{-2}$} & \multirow{3}{*}{$5 \times 10^{-2}$} & \multirow{3}{*}{$10^{-1}$} & \multirow{3}{*}{$2 \times 10^{-1}$} \\
\hline 17 & & & & & \\
\hline 20 & & & & & \\
\hline
\end{tabular}



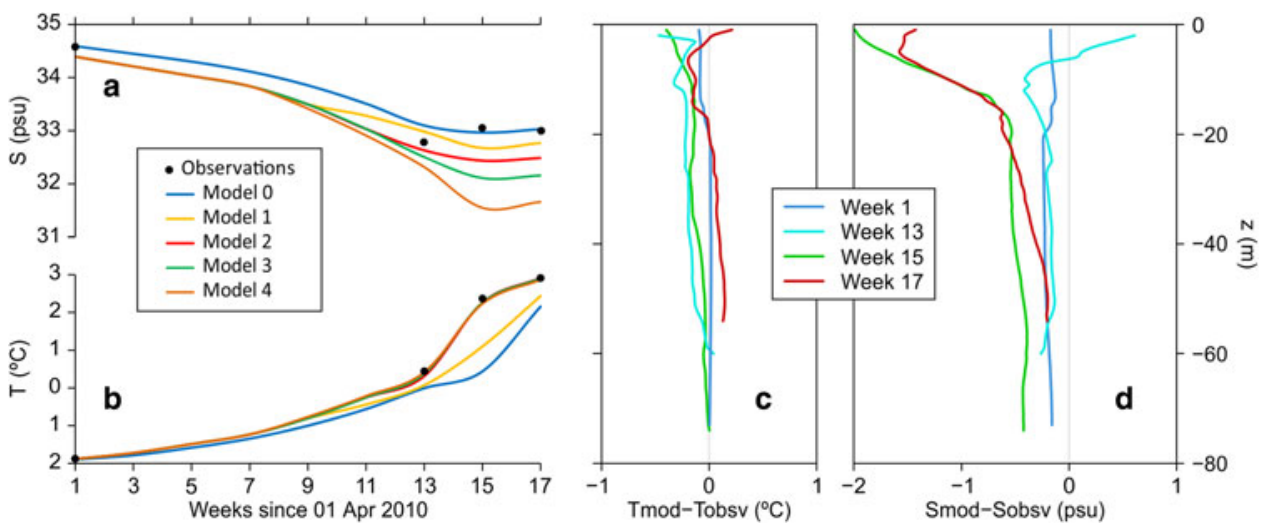

Fig. 5. Evolution of vertically averaged water properties in Hansbukta: (a) temperature $(T)$ and (b) salinity $(S)$. Each model uses different configurations of subglacial discharge velocity $\left(u_{\mathrm{sg}}\right)$, whose values can be found in Table 2 . Model 0 represents the evolution of the model when $u_{\mathrm{sg}}$ is zero over the entire simulation (blue line), and model 4 when $u_{\mathrm{sg}}$ is maximum (orange line). Black dots represent observations; (c) and (d) vertical distribution of modeled vs observed $T$ and $S$, respectively, obtained from best-fit $u_{\mathrm{sg}}$ model (model 2 ). The profiles used for comparison are those of maximum depth at the end of a simulated week, and only for those weeks with an observation profile available.

maintaining CWD equal to zero. Second, to evaluate the contribution of CWD to calving and front position, we ran the coupled model maintaining fixed the submarine melt contribution by using the best-fit subglacial discharge (i.e. scenario 1). With this configuration, we performed several runs varying CWD in two ways: (i) applying constant values of $\mathrm{CWD}=0,2$ and $3 \mathrm{~m}$; and (ii) considering surface-meltwater-dependent CWD (Eqn 10), with $f$-ratios $=$ 75, 100 and 130. This experiment will allow us to determine which configuration produces the best fit between modeled and observed front position changes, and the relative importance of each mechanism in controlling calving and/or front position.

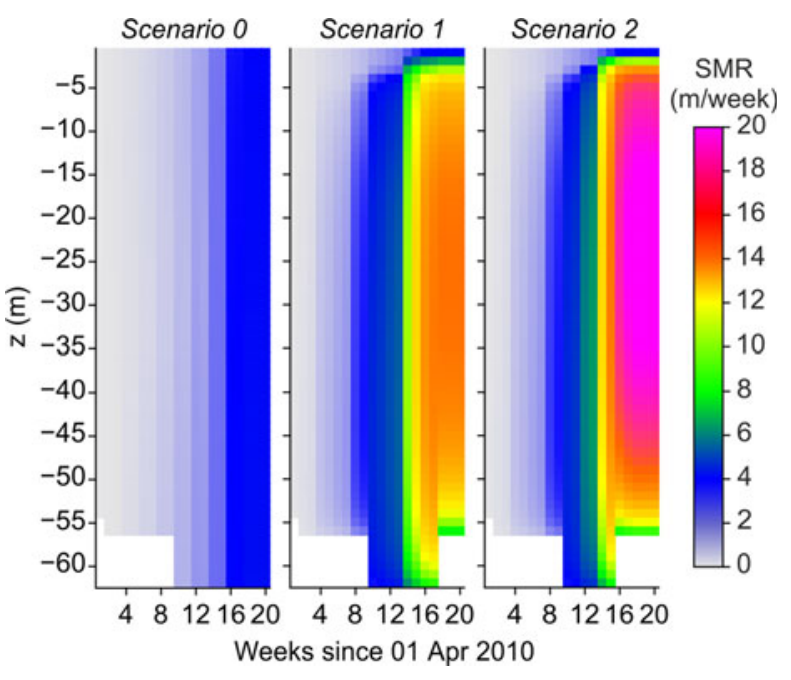

Fig. 6. Time evolution of submarine melt rates throughout the summer of 2010, under three different regimes of subglacial discharge velocities, $u_{\mathrm{sg}}$. Scenario 0 assumes zero $u_{\mathrm{sg}}$ in scenario $1 u_{\mathrm{sg}}$ varies from 0.001 (April) to $0.05 \mathrm{~m}^{3} \mathrm{~s}^{-1}$ (July-August); and $u_{\mathrm{sg}}$ reaches $0.1 \mathrm{~m}^{3} \mathrm{~s}^{-1}$ (July-August) under scenario 2 (exact $u_{\mathrm{sg}}$ fluxes of each scenario are detailed in Table 2). The glacier front moves along the irregular sea bottom, thus changing the depth of submerged ice. This is represented by the white parts on the deepest zone, where there is no ice.

\section{RESULTS AND DISCUSSION}

\subsection{Subglacial discharge}

Following previous studies, subglacial discharge intensity, $Q_{\mathrm{sg}}$, was initially constrained by estimations of SMW (e.g. Xu and others, 2012; Sciascia and others, 2013), but the velocities associated with subglacial discharge, $u_{\mathrm{sg}}$, were finally calibrated to best match observed temperature and salinity in the fjord. Due to the nearly constant vertical distribution of modeled and observed temperature and the small variations in the salinity profiles (ranging from $\sim 32$ to 34.5 psu for the entire period of simulation; Fig. 4), the profiles were vertically averaged to allow for an easy comparison of the results of our model with the observations (or interpolated data when observations were missing) every 2 weeks. Temperature and salinity in the top layer ( $5 \mathrm{~m}$ below sea level) were not considered in our calculations, since our model does not include atmospheric forcing or ice-mélange melting. Both of them could be important mechanisms in changing the physical properties of the top layers of the fjord waters, and necessary to close the heat and salt budget in our system. The point of maximum fjord depth ( 200 - 350 m downfjord from the glacial front) was selected for the comparison to collect the maximum information of the water column while avoiding the direct influence of the brackish buoyant plume. This decision was supported by the small differences observed along the rest of the fjord (see Supplementary material, Fig. S4). As mentioned earlier, estimations of minimum subglacial discharge velocities obtained from SMW were of $2 \times 10^{-3} \mathrm{~m} \mathrm{~s}^{-1}$. Nevertheless, fresh water discharge velocities in April (weeks 1-4) had to be reduced by half the corresponding discharge values for those dates, in order to avoid significant departures of the water properties. This could be primarily due to the limitations inherent to our 2-D model, which does not allow lateral ( $y$-direction) mixing or redistribution of fjord and plume waters and make our fjord waters highly sensitive to fresh water inputs. Also note that we have used SMW estimations calculated for our simulating period, which involve minimum runoffs of $3 \mathrm{~m}^{3} \mathrm{~s}^{-1}$. If there is a time lag between surface meltwater production and subglacial discharge fluxes, we are not accounting for the estimations of SMW prior to our simulations. Therefore, the time needed by SMW to reach the fjord waters could also 


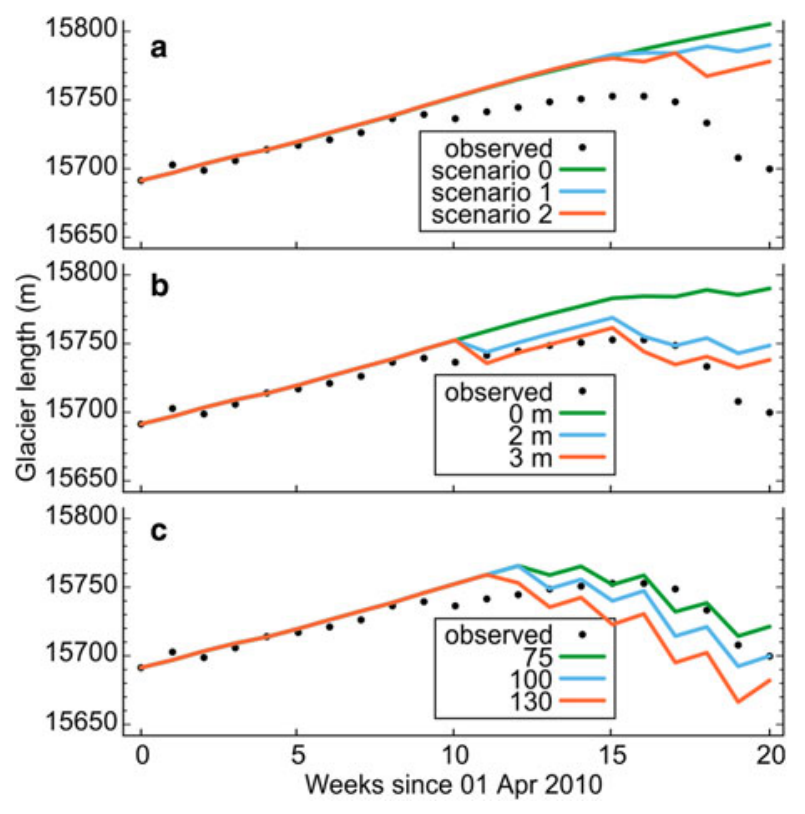

Fig. 7. Time evolution of Hansbreen front position for different simulations. (a) The coupled model run without the influence of crevasse water pressure $(C W D=0 \mathrm{~m})$ and assuming three different scenarios of submarine melt rate (evolution of subglacial discharge intensities, $u_{\mathrm{sg}}$, throughout the entire simulation period can be found in Table 2): zero $u_{\mathrm{sg}}$ (scenario 0 ), best-fit $u_{\mathrm{sg}}$ (scenario 1 ) and enhanced $u_{\mathrm{sg}}$ (scenario 2). (b) The coupled model run assuming submarine melting of scenario 1 (best fit) and CWD with various constant values $(C W D=0 \mathrm{~m}$, green; $C W D=2 \mathrm{~m}$, blue; $\mathrm{CWD}=3 \mathrm{~m}$, orange). (c) The model also runs assuming submarine melting of scenario 1, but CWD is now a function of surface melting (Eqn (10)), with $f$-ratios of 75 (green line), 100 (blue line) and 130 (orange line). Observations are represented as black dots.

be considered as a potential source of uncertainty and it is discussed latter in the text. Modeled temperature experienced high sensitivity to lower values of $u_{\mathrm{sg}}$, particularly during the last weeks of the simulations. For every evaluated period, there is a threshold of $u_{\text {sg }}$ from which the temperature reaches an equilibrium point that precisely matches the observations, and thereafter becomes practically insensitive to the $u_{\mathrm{sg}}$ values assessed in our study. However, the opposite pattern is exhibited by the modeled salinity: the higher the $u_{\mathrm{sg}}$, the worse the agreement between modeled and observed salinity. An explanation for such behavior could be that, at low flow rates, the buoyancy of the plume is not strong enough to create the overturning that would draw in warmer waters from the fjord mouth, while at higher flow rates, the amount of fresh water is too large and reduces the salinity in the fjord, likely due to the lack of the third dimension in our 2-D model. Water temperature and velocities in the vicinity of the glacier front are the main variables controlling submarine melting in our system, and thus we are interested in representing them as accurately as possible. Therefore, we calibrated $u_{\mathrm{sg}}$ as that producing the best fit to the observed temperature that our model is able to reproduce, while maintaining a fair agreement with the observed salinity (see Supplementary material, Figs S2 and S5). The resulting discharge velocities that best fitted observations ranged from $10^{-3} \mathrm{~m} \mathrm{~s}^{-1}$ in early April to $5 \times 10^{-2} \mathrm{~m} \mathrm{~s}^{-1}$ in August (Table 2). Considering that the results should be evenly distributed over the missing $y$-direction and that the estimations of SMW reached $9 \mathrm{~m}^{3} \mathrm{~s}^{-1}$, our 2-D best-fit model would conceptually represent a fjord up to $200 \mathrm{~m}$ wide for weeks with maximum fresh water inputs (weeks 15-20). This means that we are assuming a buoyant plume whose maximum lateral spreading is of $200 \mathrm{~m}$, which is probably unrealistic for a $1.5 \mathrm{~km}$-wide fjord. The overfreshening resulted from our fjord model point to the limitation derived from the lack of the third dimension, which in turn allow plume waters to laterally spread and mix over the rest of the fjord, not just along the $200 \mathrm{~m}$ that our model is able to reproduce. Our $u_{\mathrm{sg}}$ velocities for a 2-D model were considerably lower than those used by $\mathrm{Xu}$ and others (2012) for Store glacier. This could be due to the different size of the modeled systems, since SMW fluxes in our system is over ten times lower than that estimated for Store glacier (9 vs $100 \mathrm{~m}^{3} \mathrm{~s}^{-1}$ ).

In Figures 5a, b, the time evolution of observed and modeled vertically averaged temperature and salinity in the fjord is shown for different configurations of fresh water inputs (Table 2) to evaluate the effects of subglacial discharge on fjord properties. For models with higher subglacial discharges (models 2-4), temperature closely resembles the observations along the summer, whereas salinity highly differs from observations, especially at the end of the summer (up to 2 psu for model 4). For those cases with $u_{\mathrm{sg}}$ being zero or lower than best-fit values (models 0 and 1 ), the temperature inside the fjord remains up to $2^{\circ} \mathrm{C}$ colder than the observations during the 15 th week. This indicates that boundary forcing alone is not strong enough to change the water temperature inside the fjord. Our fjord needs a pump to generate circulation within the fjord, which would allow ocean properties to get into the system through the fjord mouth toward the glacier front, favoring submarine melting. Given the lack of surface forcing, subglacial discharge is the only source of momentum in the fjord. Therefore, the results of our experiment suggest that circulation in Hansbukta might be convectively driven by the buoyant plumes generated from subglacial discharge inputs, as has been demonstrated in other studies (Motyka and others, 2003, 2013; Sciascia and others, 2013; Cowton and others, 2015; Carroll and others, 2016), and that surface processes are not needed to drive the observed fjord circulation. However, for models with low $u_{\mathrm{sg}}$ (models 0 and 1), the salinity matches the observations better than those with higher $u_{\mathrm{sg}}$ (models 2-4), indicating that modeled salinity is highly sensitive to fresh water inputs. We attribute the salinity sensitivity to the limitations inherent in our 2-D model, since lateral mixing is absent.

For the best-fit configuration of $u_{\mathrm{sg}}$ (Fig. 5b, model 2, and Fig. 5c), the differences between modeled and observed temperatures were in the order of tenths of degrees Celsius or less along the entire simulation. However, modeled salinity in the fjord was more sensitive to fresh water discharge rates, which in vertical average deviated $<0.3$ psu from the salinity observations until mid-July, thereafter diverging from the observations by up to 0.6 psu in vertical average. Figure $5 d$ shows the modeled-observed salinity deviations with depth for the best-fit configuration. We see that such deviations become greater (up to 2 psu at the end of week 15) in the top layer of the fjord, where the melt plume is confined. Once more, we believe that such overfreshening confined to the top layer of the fjord is mainly due to the lack of the third dimension, which does not allow lateral mixing or a more complex water redistribution. Also note that there is an increase in observed salinity in that period (Figs 4b, c), which makes highest the difference between modeled and observed 
salinity. Physically, the two plausible ways to increase salinity in Hansbukta would be either by evaporation at the atmosphere-ocean interface, or by intrusion of saltier waters through the fjord mouth. We attribute the observed salinity increase to sudden inputs of Atlantic water, which have been reported in previous studies (Cottier and others, 2010; Walczowski and Piechura, 2011), suggesting the need of stronger ocean forcing at the open boundary in terms of velocities. Our model is unable to simulate either process, since atmospheric forcing is not solved and incoming velocities at the fjord mouth are constant in time. In spite of these differences, real conditions of $T$ and $S$ in the fjord and their evolution throughout the summer of 2010 are fairly well represented by our model under the best-fit $u_{\mathrm{sg}}$ scenario. If we compare the time evolution of the best-fit $u_{\mathrm{sg}}$ values with that of the surface runoff estimations (SMW), we observe a time lag between the two peaks of $\sim 4-5$ weeks (Supplementary material, Fig. S5). Although our model has several simplifications (e.g. 2-D geometry, Boussinesq approximation, size of the discharge channel) and sources of uncertainties (e.g. the values chosen for all coefficients) that might affect the results quantitatively, the resulted time lag could give us an indication of the transit time of SMW through the complex englacial and subglacial hydrological system until it discharges to the fjord at the grounding line. Many studies (e.g. Xu and others, 2012; Sciascia and others, 2013; Mankoff and others, 2016; Stevens and others, 2016) used SMW estimations as a proxy of subglacial discharge, assuming that all SMW discharges immediately into the fjord. However, much uncertainty remains about the hydrological processes taking place through and beneath the glacier body, as well as what proportion of SMW reaches the fjord at the grounding line vs at sea level. This finding on the time lag is neither critical to the aims of this study, nor accurately represented, since the hydrological processes are not implemented in our model. Moreover, the time resolution of our glacier model is 1 week, which constrains the precision of the time lag. Even so, it is worth to mention this time lag as a potential basis for further investigation.

\subsection{Submarine melting}

SMR at the submerged glacier terminus are highly dependent on both vertical (tangential to ice front) velocity and plume properties by virtue of Eqns (6-8). Plume properties are considered by the model to be the fjord properties in the column of gridcells adjacent to the ice front. Vertical velocities along the ice front wall are primarily the result of subglacial discharge fluxes, since they are the source of momentum in our model. Scenario 0 , which assumes zero $u_{\mathrm{sg}}$ throughout the entire summer (Table 2), simulates the submarine melting that is produced exclusively by ocean forcing, without being amplified by subglacial discharges. Melt rates at the beginning of April were in the order of millimeters per week, evolving to $1.25 \mathrm{~m} \mathrm{week}^{-1}$ in August, with maximum reached at the grounding line (Fig. 6). Submarine melting increases up to three orders of magnitude as a result of a $5^{\circ} \mathrm{C}$ increase in water temperature over the summer, which highlights the importance of considering transient fjord properties when analyzing the influence of submarine melting on calving. The resulting melt rates could at a first glance seem negligible in absolute terms, as the total mass loss of the submerged front during the modeled period would be of $0.66 \mathrm{Mt}$, i.e. $1 \%$ of the total surface melting calculated for the same period ( 70 Mt, according to Otero and others (2017)). However, when considered the cumulative melt rates per unit area over the entire simulation, oceanic forcing is almost six times more effective than atmospheric melting (8.6 vs $1.5 \mathrm{~m}$, respectively). In our system, the submerged ice front area is small and insignificant when compared with the glacier surface (with a ratio of $2: 10^{3}$ ). Nevertheless, ocean forcing could be expected to become important for large ice bodies embedded in the ocean, floating ice bodies with a large ocean/atmosphere ratio of surface exposure (e.g. ice shelves or icebergs).

Scenario 1 represents the submarine melting obtained by using the best-fit fluxes of $u_{\mathrm{sg}}$ (see values in Table 2). In Figure 6, we observe that, under scenario 1, SMR also evolve over the summer as was described for scenario 0 , but amplified by the effect of fresh water inputs, which increase tangential velocities. In April, melt rates are in the order of centimeters, and do not exceed $3 \mathrm{~m} \mathrm{week}^{-1}$ until the first week of June, then becoming comparable to observed glacier front velocities $\left(\sim 3 \mathrm{~m} \mathrm{week}^{-1}\right)$. Thereafter, melt rates increase notably, reaching maximum values above $10 \mathrm{~m}$ week $^{-1}$ at $20-30 \mathrm{~m}$ depth and over $4 \mathrm{~m}$ week $^{-1}$ at the base of the glacier, thus starting to cause retreating of the glacier grounding point and undercutting of the ice face. Both processes grounding-point retreating and undercutting are considered to potentially affect iceberg calving and glacier front position, and will be discussed later in the text. Maximum melt rates are of $\sim 15 \mathrm{~m}$ week $^{-1}$, reached at 20-30 m depth, from the end of July to the end of August (weeks 16-20), when water temperatures are higher and subglacial discharges are vigorous. Note that, although these values occur at the end of our simulation, they are likely to be the maximum over the year, since the mooring data in Figure S1 indicate that the fjord temperature is lower throughout the rest of the year. The cumulative melt estimations (at 20-30 m depth) during the entire period of simulation account for $108 \mathrm{~m}$ of submarine frontal ablation.

Under scenario 2, $u_{\mathrm{sg}}$ is doubled from week 11 (middle of June) onwards (Table 2), aiming to represent potential areas of the glacier front where the subglacial discharge could be more vigorous as the summer progresses $\left(u_{\mathrm{sg}} \max =0.1 \mathrm{~m}^{3}\right.$ $\left.\mathrm{s}^{-1}\right)$. Moreover, taking into account the limitations of our 2$\mathrm{D}$ model, we aimed to quantify the front evolution under conditions different from those obtained as more realistic. Maximum melt rates of $20.5 \mathrm{~m} \mathrm{week}^{-1}$ are reached in August and, in general, the increase in submarine melting with respect to scenario 1 is $\sim 25-30 \%$ (Fig. 6).

Under the two scenarios of non-zero $u_{\mathrm{sg}}$, maximum melt rates are reached between 20 and $30 \mathrm{~m}$ depth, coincident with highest temperatures and maximum tangential (vertical) water velocities at the ice-ocean boundary. The SMR at these depths are within the range of 1.4-20.5 $\mathrm{m} \mathrm{week}^{-1}$, which are comparable to those obtained by other modeling studies based on larger Greenlandic systems with more intense subglacial discharge fluxes (Sciascia and others, 2013; Slater and others, 2015). Our small glacier-fjord system reaches rates of submarine melting similar to those of much larger Greenlandic systems. The reason could be that our fjord temperatures during July-August are higher than those used for Greenlandic systems. This produces higher SMR in spite of the lower velocities of our model. Moreover, we have used higher spatial and temporal resolution, which 
allow us to represent smaller scale processes, as can be inferred from the sensitivity analysis (Fig. S3).

\subsection{Front position changes and calving rates}

Finally, we test the influence and relative importance of SMR and CWD on calving rates and front position changes. Seasonality in the dynamics of Hansbreen front is mostly influenced by the ice-mélange coverage and by basal sliding. From April to October, when ice mélange has disappeared, the glacier reaches terminus speeds of up to $\sim 7 \mathrm{~m}$ week $^{-1}$. Our study period focuses on this time window in order to analyze the mechanisms that influence the advance and retreat of the glacier front during the period when backpressure from sea-ice is absent (Otero and others, 2017). However, in the present study, we are not able to represent the seasonality of the glacier-fjord system, since we do not have sufficient overlapping time series of both oceanographic and glaciological data.

As a first experiment (Fig. 7a), we analyze the effects of submarine melting on glacier front position and calving, without the influence of crevasse water pressure $(C W D=$ 0 ). Our results demonstrate that the addition of submarine melting amplifies the calving rates. The larger the $u_{\mathrm{sg}}$ flux, the more intense the submarine melting, and the higher the calving rates. During the 5-month modeled period, we observe that no calving events took place under scenario 0 (no fresh water inputs). Submarine melting due to ocean forcing, without the amplification derived from subglacial fresh water discharges, is insufficient to cause instabilities to the glacier front that would result in iceberg calving and consequently in front retreat. Therefore, Hansbreen front keeps advancing at speeds of 4-7 m week ${ }^{-1}$, deviating from observations. For both scenarios 1 and 2, three calving events occurred from week 15 onwards, corresponding in time to maximum rates of submarine melting. They account for 17 and $34 \mathrm{~m}$ of cumulative frontal ablation, respectively, showing that submarine melting affects iceberg calving. However, neither scenario of submarine melting, 1 or 2, is sufficiently intense to reproduce the observed front position changes. Therefore, although submarine melting seems to be significant for Hansbreen's dynamics during late summer, having an effect on iceberg calving, it is a weak mechanism to explain front position changes when considered alone. In our study, the effects of submarine melting on calving or front position are not as remarkable as those shown by Krug and others (2015). Even under scenario 2, with submarine melting amplified with respect to that believed to be more representative of the real conditions (scenario 1), submarine melting alone is not enough to reproduce the front retreats observed at the end of the summer, suggesting the need of including other contributing mechanisms, such as water in crevasses.

The influence of CWD on calving and front position changes, under a fixed configuration of submarine melting (given by scenario 1 ) is illustrated in Figures 7b, c. If CWD is considered as constant in time (Fig. 7b), the best-fit occurs when CWD $=3 \mathrm{~m}$, which gives an average difference of $\pm 12 \mathrm{~m}$ between observed and modeled front positions, and a cumulative frontal ablation due to calving of $73 \mathrm{~m}$ over the whole modeled period. Here, we note that $3 \mathrm{~m}$ of CWD is a lower value than that of $10 \mathrm{~m}$ obtained by the original uncoupled glacier model by Otero and others (2017), which did not consider submarine melting, thus suggesting that the inclusion of submarine melting decreases the relative importance attributed to CWD. However, since our modeled period is restricted to a single summer (2010), it is not possible to analyze the effects of a constant CWD on a multiyear simulation, as done by Otero and others (2017).

From a physical perspective, it seems more sensible to assume that CWDs vary in time according to surface melting runoff (SMW) derived from atmospheric forcing. As shown in Figure $7 \mathrm{C}$, the model that best adjusts to front position observations is that with $f=75$, which produces an average deviation lower than $\pm 10 \mathrm{~m}$, and cumulative ablation by calving of $91 \mathrm{~m}$ over the entire summer. In the model by Otero and others (2017), the best-fit ratio was $f=$ 130. Such a value, applied to our model, results in an overestimation of frontal ablation and a retreat of the glacier front when compared with observations for the end of the modeled period (Fig. 7c). This discrepancy arises from the inclusion of the influence of submarine melting (in turn influenced by surface melting), leading to a decrease of the relative importance of runoff-dependent CWD as compared with the model by Otero and others (2017). The average difference between observed and modeled front positions are, in both best-fit models (with and without submarine melting), of about $\pm 10 \mathrm{~m}$, showing that the inclusion of submarine melting does not improve quantitatively the general model results in a significant way. However, the coupled model does reproduce front positions in late summer more accurately than the glacier model alone, coinciding with the period of highest submarine melting. In agreement with other studies (e.g. Morlighem and others, 2016; Seroussi and others, 2017), our results show that submarine melting is a relevant driver of frontal retreat and exerts a key control on calving (Vallot and others, 2018), but the amount of water filling the crevasses is also crucial to determine calving rates during the summer season, as indicated by Cook and others (2014) and Otero and others (2017). Therefore, our modeling suggests that submarine melting plays a significant role in the dynamics of the glacier terminus. If submarine melting is not considered in the model, larger amounts of water in surface crevasses are required to offset the terminus position so that better agreement with observations is achieved.

\section{CONCLUSIONS}

We have used a 2-D high-resolution coupled glacier-fjord model, with observed bathymetry, to investigate the processes occurring in Hansbreen-Hansbukta system, in Svalbard. We focused on the effect of subglacial fresh water discharge on fjord properties and SMR, and the effects of SMR and CWD on calving and glacier front position changes.

Our results suggest that water temperature is sensitive to low values of subglacial discharge inputs, because the model loses the ability of drawing in warmer waters through the fjord mouth, i.e. the convection-driven circulation is cancelled. Salinity in Hansbukta is highly sensitive to non-zero subglacial discharge inputs, likely due to the limitations in lateral dynamics inherent to our 2-D model. Nevertheless, fjord circulation may be represented by adjusting subglacial discharge velocities, since a compromise can be made between accurate representation of the bulk fjord properties and those of the plume, which both affect submarine ice melting. The subglacial discharge required to fit the 
observed $T$ and $S$ of the fjord waters during April-May appear to be smaller than runoff estimations available for that period, which could be due to the time lag of 4-5 weeks found between peaks of SMW runoff and subglacial discharge. During latter summer (July-August), we obtained best-fit subglacial discharge velocities of $0.05 \mathrm{~m} \mathrm{~s}^{-1}$. From the results of our simulations, we see that subglacial discharge promotes convective circulation within the fjord, which favors the intrusion of warm and salty Atlantic waters. This fact results in evolving temperature, salinity and velocities of the fjord waters throughout the summer, with increasing melt rates in the submerged ice front wall as the summer progresses, from centimeters up to $15 \mathrm{~m}$ week ${ }^{-1}$. Therefore, one should be aware about the significant effect of the transient fjord properties when estimating submarine melting throughout a given time period.

Our model results indicate that submarine melting amplifies calving rates. However, submarine melting alone (together with its feedback on calving) is unable to reproduce the observed front position changes of Hansbreen. Only when considering the joint influence of both submarine melting and CWD is our coupled model able to reproduce the temporal evolution of Hansbreen front position with a maximum deviation of $\pm 10 \mathrm{~m}$ from the observations. Finally, linear cumulative mass losses over the modeled period due to submarine melting and to calving processes are of the same order of magnitude for Hansbreen (108 and $91 \mathrm{~m}$, respectively), which raises the interest of further studies to better understand the relative contribution to SLR of the two main components of frontal ablation for tidewater glaciers.

\section{SUPPLEMENTARY MATERIAL}

The supplementary material for this article can be found at https://doi.org/10.1017/jog.2018.61.

\section{ACKNOWLEDGEMENTS}

This project has received funding from the European Union's Horizon 2020 research and innovation program under grant agreement No. 727890 and by projects CTM2014-56473-R and CTM2017-84441-R of the Spanish State Plan for R\&D. EDA is supported by the Spanish Ministry of Education under FPU-14/01409 PhD contract. Field measurements in Hornsund were supported by the Polish-Norwegian project AWAKE-2 (contract No. Pol-Nor/198675/17/2013).

\section{REFERENCES}

Aas KS and 6 others (2016) The climatic mass balance of Svalbard glaciers: a 10-year simulation with a coupled atmosphereglacier mass balance model. Cryosphere 10, 1089-1104

Arakawa A and Lamb VR (1977) Computational design of the basic dynamical processes of the UCLA general circulation model. Methods Comput. Phys. 17, 173-265 https://ntrs.nasa.gov/ search.jsp?R=19780026757.

Arthern RJ and Gudmundsson GH (2010) Initialization of ice-sheet forecasts viewed as an inverse Robin problem. J. Glaciol. 56, $527-533$

Benn DI, Hulton NRJ and Mottram RH (2007) 'Calving laws', 'sliding laws' and the stability of tidewater glaciers. Ann. Glaciol. 46, 123-130
Blaszczyk M, Jania JA and Hagen JO (2009) Tidewater glaciers of Svalbard: recent changes and estimates of calving fluxes. Polish Polar Res. 30, 85-142.

Carroll D and 5 others (2015) Modeling turbulent subglacial meltwater plumes: implications for fjord-scale buoyancy-driven circulation. J. Phys. Oceanogr. 45, 2169-2185

Carroll D and 11 others (2016) The impact of glacier geometry on meltwater plume structure and submarine melt in Greenland fjords. Geophys. Res. Lett. 43, 9739-9748

Chen F and Dudhia J (2001) Coupling an advanced land surfacehydrology model with the Penn State-NCAR MM5 modeling system. Part II: preliminary model validation. Mon. Weather Rev. 129, 587-604

Church JA and 13 others (2013) Sea level change. In Stocker TF, Qin D, Plattner G-K, Tignor M, Allen SK, Boschung J, Nauels A, Xia Y, Bex V and Midgley PM, eds. Climate change 2013: the physical science basis. Contribution of working group I to the fifth assessment report of the intergovernmental panel on climate change. Cambridge University Press, Cambridge, New York, UK, 1137-1216.

Cook S, Zwinger T, Rutt IC, O'Neel S and Murray T (2012) Testing the effect of water in crevasses on a physically based calving model. Ann. Glaciol. 53, 90-96

Cook S and 7 others (2014) Modelling environmental influences on calving at Helheim Glacier in eastern Greenland. Cryosphere 8, 827-841

Cottier FR and 5 others (2010) Arctic fjords: a review of the oceanographic environment and dominant physical processes. Ceol. Soc. London 344, 35-50

Cowton T, Slater D, Sole A, Goldberg D and Nienow P (2015) Modeling the impact of glacial runoff on fjord circulation and submarine melt rate using a new subgrid-scale parameterization for glacial plumes. J. Geophys. Res. Oceans 120, 796-812

Cowton T and 5 others (2016) Controls on the transport of oceanic heat to Kangerdlugssuaq Glacier, East Greenland. J. Glaciol. 62, 1167-1180

Finkelnburg R (2013) Climate variability of Svalbard in the first decade of the 21st century and its impact on Vestfonna ice cap, Nordaustlandet. Technische Universität Berlin (doi: 10.14279/depositonce-3598).

Gardner AS and 15 others (2013) A reconciled estimate of glacier contributions to sea level rise: 2003 to 2009. Science (80-.). 340, 852-857

Grabiec M, Jania J, Puczko D, Kolondra L and Budzik T (2012) Surface and bed morphology of Hansbreen, a tidewater glacier in Spitsbergen. Polish Polar Res. 33, 111-138

Holland DM and Jenkins A (1999) Modeling thermodynamic iceocean interactions at the base of an ice shelf. J. Phys. Oceanogr. 29, 1787-1800

Huss M and Hock R (2015) A new model for global glacier change and sea-level rise. Front. Earth Sci. 3(September), 1-22

Israeli M and Orszag SA (1981) Approximation of radiation boundary conditions. J. Comput. Phys. 41, 115-135

Jackett DR and Mcdougall TJ (1995) Minimal adjustment of hydrographic profiles to achieve static stability. J. Atmos. Ocean. Technol. 12, 381-389

Jay-Allemand M, Gillet-Chaulet F, Gagliardini O and Nodet M (2011) Investigating changes in basal conditions of Variegated Glacier prior to and during its 1982-1983 surge. Cryosphere 5, 659-672

Jenkins A (2011) Convection-driven melting near the grounding lines of ice shelves and tidewater glaciers. J. Phys. Oceanogr. 41, 2279-2294

Jenkins A, Nicholls KW and Corr HFJ (2010) Observation and parameterization of ablation at the base of Ronne Ice Shelf, Antarctica. J. Phys. Oceanogr. 40, 2298-2312

Krug J, Durand G, Gagliardini O and Weiss J (2015) Modelling the impact of submarine frontal melting and ice mélange on glacier dynamics. Cryosphere 9, 989-1003

Lang C, Fettweis X and Erpicum M (2015) Future climate and surface mass balance of Svalbard glaciers in an RCP8.5 climate scenario: 
a study with the regional climate model MAR forced by MIROC5. Cryosphere 9, 945-956

Losch M (2008) Modeling ice shelf cavities in a z coordinate ocean general circulation model. J. Geophys. Res. 113, C08043

Luckman A and 5 others (2015) Calving rates at tidewater glaciers vary strongly with ocean temperature. Nat. Commun. 6, 8566

Mankoff KD and 5 others (2016) Structure and dynamics of a subglacial discharge plume in a Greenlandic fjord. J. Geophys. Res. Oceans 121, 8670-8688

Marshall J, Adcroft A, Hill C, Perelman L and Heisey C (1997) A finite-volume, incompressible Navier Stokes model for studies of the ocean on parallel computers. J. Geophys. Res. Oceans 102, 5753-5766

McPhee MG, Maykut GA and Morison JH (1987) Dynamics and thermodynamics of the ice/upper ocean system in the marginal ice zone of the Greenland Sea. J. Geophys. Res. 92, 7017

Möller M, Navarro F and Martín-Español A (2016) Monte Carlo modelling projects the loss of most land-terminating glaciers on Svalbard in the 21 st century under RCP 8.5 forcing. Environ. Res. Lett. 11, 94006

Morlighem M and 6 others (2016) Modeling of Store Gletscher's calving dynamics, West Greenland, in response to ocean thermal forcing. Geophys. Res. Lett. 43, 2659-2666

Motyka RJ, Hunter L, Echelmeyer KA and Connor C (2003) Submarine melting at the terminus of a temperate tidewater glacier, LeConte Glacier, Alaska, U.S.A. Ann. Glaciol. 36, 57-65

Motyka RJ, Dryer WP, Amundson J, Truffer M and Fahnestock M (2013) Rapid submarine melting driven by subglacial discharge, LeConte Glacier, Alaska. Geophys. Res. Lett. 40, 5153-5158

Navarro FJ and 6 others (2014) Ice volume estimates from groundpenetrating radar surveys, Wedel Jarlsberg Land Glaciers, Svalbard. Arctic Antarct. Alp. Res. 46, 394-406

Nick FM, Van der Veen CJ, Vieli A and Benn DI (2010) A physically based calving model applied to marine outlet glaciers and implications for the glacier dynamics. J. Glaciol. 56, 781-794

Nye JF (1957) The distribution of stress and velocity in glaciers and ice-sheets. Proc. R. Soc. A Math. Phys. Eng. Sci. 239, 113-133

O'Leary M and Christoffersen P (2013) Calving on tidewater glaciers amplified by submarine frontal melting. Cryosphere 7 , $119-128$

Østby TI and 5 others (2017) Diagnosing the decline in climatic mass balance of glaciers in Svalbard over 1957-2014. Cryosphere 11, 191-215

Otero J, Navarro FJ, Martin C, Cuadrado ML and Corcuera MI (2010) A three-dimensional calving model: numerical experiments on Johnsons Glacier, Livingston Island, Antarctica. J. Glaciol. 56, 200-214

Otero J and 5 others (2017) Modeling the controls on the front position of a tidewater glacier in Svalbard. Front. Earth Sci. 5, 29

Pẹtlicki M, Ciepły M, Jania JA, Promińska A and Kinnard C (2015) Calving of a tidewater glacier driven by melting at the waterline. J. Glaciol. 61, 851-863
Pfeffer WT and 18 others (2014) The Randolph Glacier Inventory: a globally complete inventory of glaciers. J. Glaciol. 60, 537-552

Puczko D (2012) Czasowa i przestrzenna zmienność ruchu spitsbergeńskich lodowców uchodzạcych do morza na przykładzie lodowca hansa.

Rignot E, Koppes M and Velicogna I (2010) Rapid submarine melting of the calving faces of West Greenland glaciers. Nat. Geosci. 3, 187-191

Sciascia R, Straneo F, Cenedese C and Heimbach P (2013) Seasonal variability of submarine melt rate and circulation in an East Greenland fjord. J. Geophys. Res. Oceans 118, 2492-2506

Seroussi H and 6 others (2017) Continued retreat of Thwaites Glacier, West Antarctica, controlled by bed topography and ocean circulation. Geophys. Res. Lett. 44, 6191-6199

Slater DA, Nienow PW, Cowton TR, Goldberg DN and Sole AJ (2015) Effect of near-terminus subglacial hydrology on tidewater glacier submarine melt rates. Geophys. Res. Lett. 42, 2861-2868

Slater DA, Goldberg DN, Nienow PW and Cowton TR (2016) Scalings for submarine melting at tidewater glaciers from buoyant plume theory. J. Phys. Oceanogr. 46, 1839-1855

Slater DA, Nienow PW, Goldberg DN, Cowton TR and Sole AJ (2017a) A model for tidewater glacier undercutting by submarine melting. Geophys. Res. Lett. 44, 2360-2368

Slater D and 6 others (2017b) Spatially distributed runoff at the grounding line of a large Greenlandic tidewater glacier inferred from plume modelling. J. Glaciol. 63, 309-323

Stevens LA and 5 others (2016) Linking glacially modified waters to catchment-scale subglacial discharge using autonomous underwater vehicle observations. Cryosphere 10, 417-432

Straneo F and Heimbach P (2013) North Atlantic warming and the retreat of Greenland's outlet glaciers. Nature 504, 36-43

Todd J and Christoffersen P (2014) Are seasonal calving dynamics forced by buttressing from ice mélange or undercutting by melting? Outcomes from full-stokes simulations of Store Glacier, West Greenland. Cryosphere 8, 2353-2365

Vallot D and 9 others (2018) Effects of undercutting and sliding on calving: a global approach applied to Kronebreen, Svalbard. Cryosphere 12, 609-625

Van der Veen CJ (1996) Tidewater calving. J. Glaciol. 42, 375-385

Vieli A, Jania J and Kolondra L (2002) The retreat of a tidewater glacier: observations and model calculations on Hansbreen, Spitsbergen. J. Glaciol. 48, 592-600

Walczowski W and Piechura J (2011) Influence of the West Spitsbergen Current on the local climate. Int. J. Climatol. 31, 1088-1093

Xu Y, Rignot E, Menemenlis D and Koppes M (2012) Numerical experiments on subaqueous melting of Greenland tidewater glaciers in response to ocean warming and enhanced subglacial discharge. Ann. Glaciol. 53, 229-234

Xu Y, Rignot E, Fenty I, Menemenlis D and Flexas MM (2013) Subaqueous melting of Store Glacier, west Greenland from three-dimensional, high-resolution numerical modeling and ocean observations. Geophys. Res. Lett. 40, 4648-4653 